\title{
Profile of the Fashion E-Consumers: A Key for Online Fashion Business Success
}

\author{
Shuvo K Kundu* \\ Central Michigan University, USA
}

*Corresponding author: Shuvo K Kundu, Central Michigan University, Mount

Pleasant, Michigan, USA.

Received Date: November 05, 2018

Published Date: November 19, 2018

\begin{abstract}
Online Shopping is now a well-known term for the people of all ages. With the expansion of technologies and increasing use of internet, online market is blooming at a noticeable rate. Competition among online companies to increase sale by create new customer, make their shopping cart full, and make customers repurchase. To do this companies need to have an idea on cluster of their target customer and customers' demand. Researcher trying to group homogenous customers based on different parameters for decades. The purpose of this study was to review profile of online customer investigated by researcher in the past and summarize. This study reviewed customer profiles from different perspective such as Shopping Orientation, Lifestyle Factors, E-Retailer's Attributes, and Demographics. More than hundred published research were studied from where forty studies were cited in this study. The significance of this research was to understand how customers of a profile also related to other parameters of different profile and understand combined characteristic of a group of customer form different profile studied by different researchers. This study found relation between consumers of different type and multiple construct of online shopping.
\end{abstract}

Keywords: Online; Online shopping; Online shoppers; Online market; E-Shopper; E-Commerce; Internet; Fashion.

\section{Introduction}

Online is the thriving market for fashion as number of internet user increasing every year. Adrita UW et al. [1] also found that, the trend of internet use and online shopping in increasing day by

day. Other researchers stated that the use of the internet has had a positive relationship with online shopping (Sia et al., 2009; Sung and Jeon, 2009).

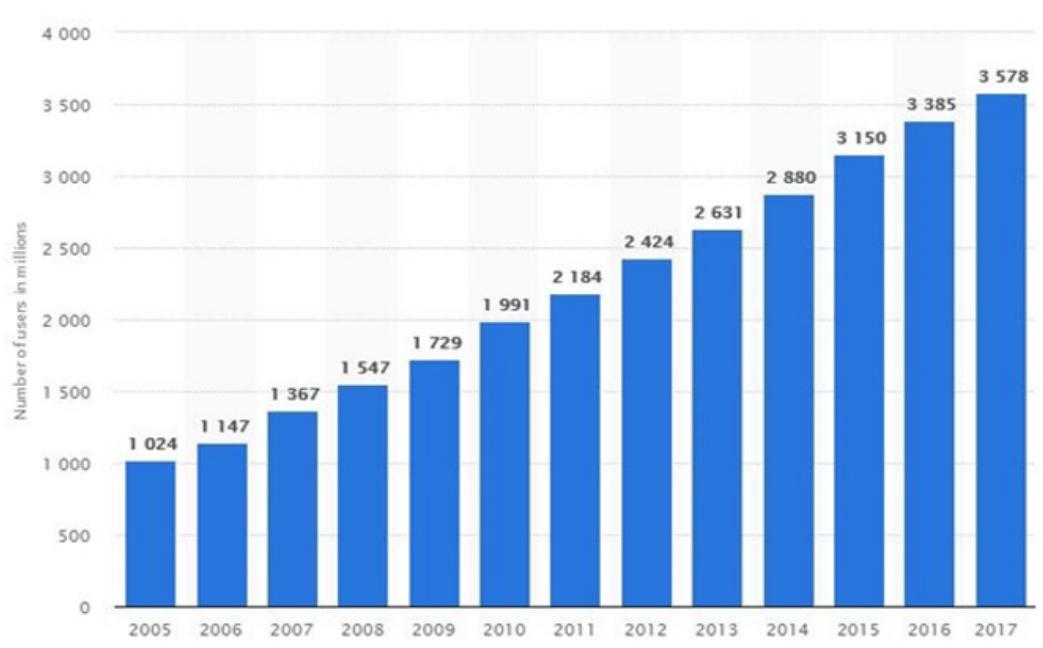

Figure 1: Number of internet users worldwide from 2005 to 2017 (Statista, 2017). 
In 2017, the number of internet users was 3.58 billion worldwide, which was 1.02 million in 2005 (Figure 1). As of March 2017, about 731 million internet users were Chinese and 287 million were American [2]. Therefore, with the increasing number of internet users, there is a potential online fashion market worldwide. Worldwide Retail e-commerce sales as forecasted to be twice between 2016 and 2020. A survey on April 2017 revealed than 40 percent of American internet users shop online a few times every month and 20 shopped online once in a week. Online sales only in USA will be increased from 287 billion in 2014 to 523 billion in 2020 [3], Figure 2).

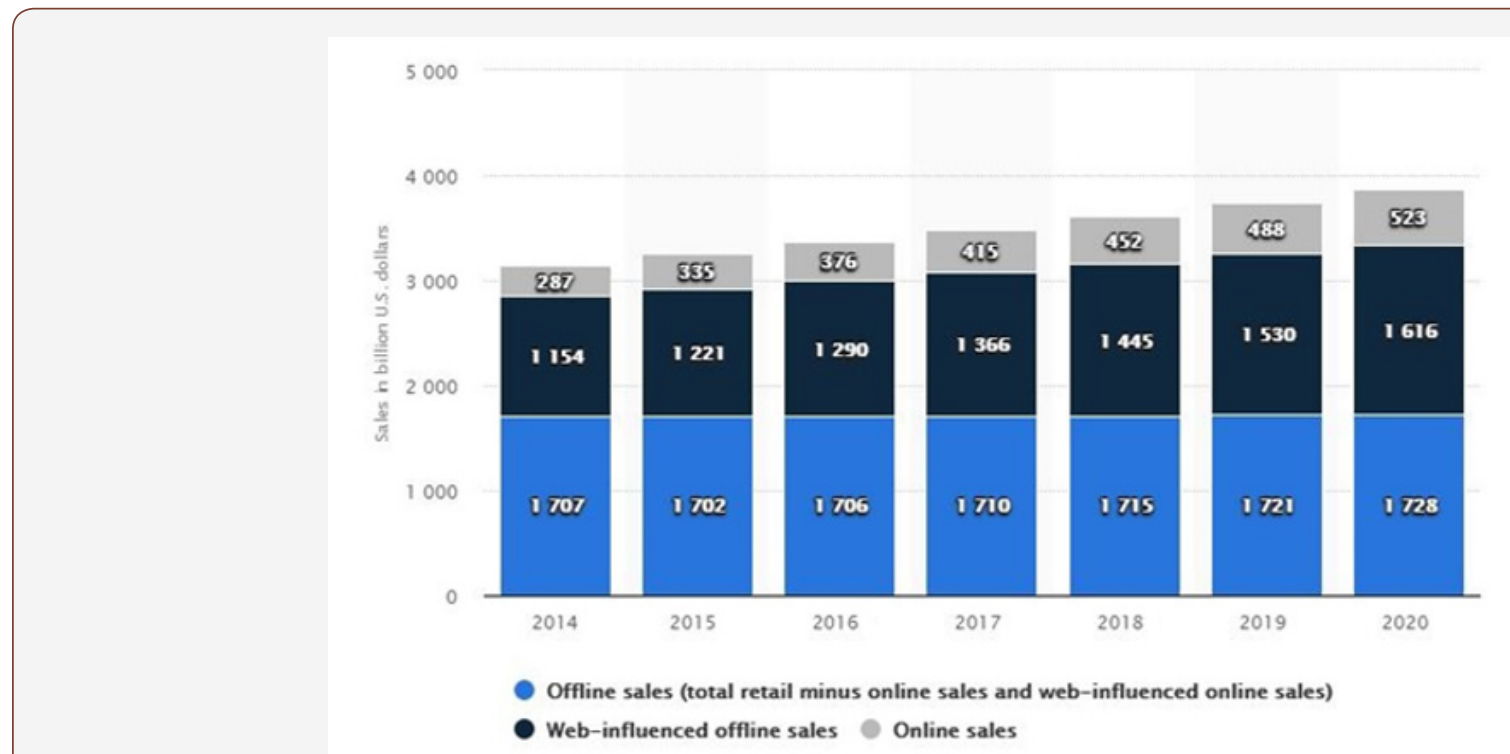

Figure 2: Web-influenced retail sales in the United States from 2014 to 2020 (Statista, 2016).

Therefore, it is important to define the profile of online fashion buyers since there is a high online fashion business potential worldwide. Vyncke P [4] stated that profiling consumers are important for recognize the homogenous groups in the same market. Homogenous groups exhibit similar demand and/or interest within segmentations such as lifestyle or demographics. It is also possible that in the same online market can be too heterogeneous by needs and/or interests. Well defined consumer profile of an online market will help companies to know what their consumers wants and what will be the marketing policy of the company.

\section{Discussion}

\section{Shopping orientation}

Researchers studying consumers' shopping orientation over the last three decades [5]. Researchers found different construct of online consumers' behaviors and these constructs are the preference of online vs offline shopping [6], and opportunity and challenges of online commerce [7]. Some investigators studied consumers' profile of the different target group and different construct. The constructs include involvement, innovativeness, self-expression and impulsiveness [8], web site characteristics, product involvement and online shopping experience, retailer's attribute and demographics [9], and lifestyle and online shopping mall attributes.

Sung and Jeon [10], found that internet users belong to one of the five groups based on their fashion lifestyle. According to Sung [10], fashion and brand shoppers are highly conscious about the current trend of fashion and renowned fashion brand but surprisingly they do not enjoy shopping. Recreational Shoppers enjoy shopping, conscious of brand name moderately and care about the value of what they are spending. Economical Shoppers possess a higher level of economic orientation and personality but not interested regarding shopping, fashion and brand names. Individualistic Shoppers care about personality and well-dressed rather than fashion trends, moreover they moderately enjoy shopping like Recreational Shoppers. Finally, Fashion Followers are the largest group among five segments, but they have less interest in fashion, brands, and shopping. Lima Filho et al. [11], segmented 117 undergraduate Brazilian students in four different segments based on their habits, preferences, and socio-demographic characteristics. The segments were Controlled Consumer, Young Consumer, Basic Consumer, and Conventional Buyer. Controlled Consumers are neither impulsive shopper nor shop for pleasure. They would rather care about security while shopping and they only buy what they want to. Young Consumers prefer to shop without leaving home, they enjoy online shopping and also seek security during shopping online. Basic Consumers purchase quickly, and they are risk takers, they consider price in terms of quality. Conventional Buyers prefer purchase outside of their home, being helped by salesperson and seek for security. Besides that, they are impulse buyers and enjoy shopping to the highest extent. Lima Filho et al. [12], also stated that men do more online fashion shopping than women and online fashion consumption is related to the income and use of credit cards.

Bloch PH [13] stated that product involvement is the emotional attachment of consumers to the product, which also reflects the amount of interest and personal relationship with the product. Stith MT, et al. [14] described innovativeness as consumers' intention to buy new and innovative fashion and change the conventional taste of dress up. Rogers EM, et al. [15,16], defined innovativeness as the 
degree to which a consumer agrees to own new ideas comparatively earlier than other people in the society. Belk RW [17] expressed self-expression as 'We are what we have'. Consumers' choice is a form of their self-expression either by expressing 'this is who I am' or 'this is what I want to become' [18]. Kacen JJ [19] and Chen T $[20,21]$ stated that Impulsiveness is a reckless and unplanned action of shopping driven by very rapid decision-making process. Wang [22], segmented Generation Y based on socioeconomic data, shopping motivation characteristics and attitude toward shopping, direct marketing, and advertising.

\section{Lifestyle factors}

Lifestyle Factors is a psychographic analysis which describes the way consumers expressed themselves in a social and cultural environment. Using lifestyle as a segment can be a leading success factor for a retail organization over other segmentation like demographics or merchandise can do [23]. Blackwell RD, et al. [24] defined lifestyle as "patterns in which people live and spend time and money, reflecting a person's activities, interests, and opinions, as well as demographic variables". Lifestyle factors consist of fashion consciousness, shopping enjoyment, brand consciousness, personality pursuit and economic orientation.

\section{E-Retailer's attributes}

Researcher stated like brick-and-mortar retailers, e-retailers also have some unique characteristics which are called retailer's attributes. A retailer's attributes are comprising of product description and/or information, website design, product assortment, the speed of downloading, easy of ordering, customer support, shipping and handling, order tracking, and on-time delivery [25,26,27]. Jiang P [28] reported that consumers' intention to repurchase increases from same online retail store depends on customer satisfaction at checkout and customer satisfaction after delivery. Online retailer's performance of services is significantly important to make loyal buyers from first-time customers. If the first-time buyer satisfies on the website performance and services, they return to shopping from the same online retailer frequently and buy more products. Sung H, et al. $[10,29]$ stated that there are four main retailer's attributes with many sub-attributes and they are product presentation attribute, check out attribute, after service attribute from.

Product presentation attributes are the characteristic of online fashion business related with visualizing merchandise to the online consumers in a better and attractive way. It consists of website design, the speed of product search, product description, product information, the variety of product, perceive of usefulness, ease of use and convenience. Sub-attributes are website design [10,3032] speed of product search, product description [10], product information [33], variety of product [34,10], perceive usefulness $[35,36]$, ease of use $[36,37]$ and convenience [38].

Checkout attributes are online retailers' characteristics influence consumers to make a decision during checkout of online fashion shopping. Checkout attributes are consisting of price perception, the method of payment, ease of payment, visit points/ giveaways, membership incentive, ease of ordering, order tracking, reputation, and trust. Sub-attributes are price perception [39,40], method of payment, ease of payment, order tracking, visit point/ giveaways, membership incentive, ease of ordering, reputation, and trust. Studies defined security attributes of online shopping are website transparency, privacy, and payment security. After Service is an important attribute of online retailers' which influences consumers to make a decision of repurchasing from the same online retailer. After service attributes are consisting of customer support, on-time delivery, return policy, product met expectation, overall satisfaction, intention to purchase, the interactivity of seller and feedback [32].

\section{Demographics}

Sung H, et al. [10] stated demographics as study of consumers depending on different physical attributes like sex, age, race, ethnicity, income, marital status etc. These attributes can be observed easily and identify homogeneous groups among target consumer group. Demographic attributes express who buy products and demographic characteristics are unique, a consumer's interest or buying behavior about fashion items would lead to the different buying process. Demographics is a very important factor to segment consumers and understand changes in buying ability and buying behavior. Passyn KA, et al. [26], also studied the level of education, major studied, marital status and ownership of home alongside other demographic variables. Kim EY, et al. [9], found that the online shopping intentions for accessories (e.g. jewelry) will be anticipated by different combinations of online shopping attributes and demographic variables.

\section{Conclusion}

Sung H, et al. [10], investigated that one out of five shoppers are economical shopper and they possessed second highest levels of economic orientation and personality pursuits. They are not enthusiastic in brands, fashion and/or shopping. Mostly male, government job holder and elderly people consist of this consumer group. Lee SE, et al. [2], stated that like Utilitarian Shopper, Economical Shoppers don't like searching merchandise or social communication rather they like the convenience and controlled shopping. On the other hand, Economical Shopper is the opposite of the Recreational Shopper even after both are careful of economic aspects. Moreover, the Recreational Shopper enjoys shopping and bear positive intention regarding e-retailers, while the Economic Shopper shows a low range of judgment for e-retailers.

Recreational Consumers enjoy shopping very much and always care about price and about the brand with mid-level priority. Most of the consumers in this group are female, young students or housewives and their occupations likely related to their gender and age. Bellenger DN et al. [3] presented that recreational shoppers spent more time even after making a purchase online, search for information and bargain more than Economical Shoppers. This research again remarked that Recreational Shoppers value high-quality, variety of products and visual form of the retailer. Recreational shoppers are practical and they visit retailer's website for gathering information besides shopping. They are a very important segment for online fashion retailer due to their frequent online visit and higher intention of purchase. 
Sung H [10], examined that fashion followers are the biggest group of the sample. This group expresses propensity to fashion leaders, but expresses comparatively lower propensity to fashion, brand names, and do not enjoy shopping. This group is careless about price or practical features of fashion products, the economic orientation of fashion followers is at the bottom, although they have lowest household income among all group. The website visit vs purchase items ratio is lowest for this group. It guessed that they either afraid or not familiar with internet checkout process. They always value benefit of shopping and after sell service and create the positive attitude toward online fashion shopping.

The Individualistic Shoppers do not care about the economic aspects but care about brand names thus they can have dressed well. This group evaluate fashion e-retailer attributes, become satisfied as well as intend to purchase at a moderate level. They are less frequent website visitor, so marketing strategy should be designed for them to make them proactive shoppers.

\section{Acknowledgement}

This review article was written under the supervision of Dr. Usha Chowdhary, Professor, Department of Fashion Merchandising and Design, Central Michigan University as a part of FMD 604 Scholarship and Textiles and Clothing course. I want to thank Dr. Chowdhary for her immense support, supervision, and advise throughout the research. I also want to thank my classmates for their support to complete my research.

\section{Conflict of Interest}

There is no conflict of interest and/or authorship.

\section{References}

1. Adrita UW, Shahjahan T, Ummul W (2016) Preference of shopping on online vs offline in Bangladesh. J Arts, Science and Commerce 7(3): 6472.

2. Kacen JJ, Lee JA (2002) The influence of culture on consumer impulsive buying behavior. Journal of Consumer Psychology 12(2): 163-176.

3. Bellenger DN, Korgaonkar PK (1980) Profiling the recreational shopper. J Retailing 56(3): 77-92.

4. Rahman MM, Sloan $T$ (2015) Opportunities and challenges of m-commerce adoption in Bangladesh: an empirical study. Journal of Internet Banking and Commerce 20(3): 1-24.

5. Hsieh JY, Liao PW (2011) Antecedents and moderators of online shopping behavior in undergraduate students. Social Behavior and Personality 39(9): 1271-1280.

6. Breitenbach CS, Van Doren DC (1998) Value-added marketing in the digital domain: enhancing the utility of the Internet. J Consumer Marketing 15(6): 558-575

7. (2017) Number of internet users worldwide from 2005 to 2017

8. Bloch PH (1986) The product enthusiast: implications for marketing strategy. J Consumer Marketing 3(3): 51-62.

9. Kim EY, Youn-Kyung K (2004) Predicting online purchase intentions for clothing products. European Journal of Marketing 38(7): 883-897.

10. Lee SE, Littrell MA (2005) Global e-tailing: US consumers' intention to shop for cultural products on the internet. International Journal of Retailing and Distribution Management 33(2): 133-147.

11. Stith MT, Goldsmith RE (2006) Race, sex, and fashion innovativeness: A replication. Psychology and Marketing 6(4): 249-262.
12. Gutman J, Mills MK (1982) Fashion life style, self-concept, shopping orientation, and store patronage: an integrative analysis. Journal of Retailing 58(2): 64-86.

13. Sung TK (2006) E-commerce critical success factors: East vs West. Technological Forecasting and Social Change 73(9): 1161-1177.

14. Sung H, Jeon Y (2009) A profile of Koreans: who purchases fashion goods online? Journal of Fashion Marketing and Management: An International Journal 13(1): 79-97.

15. Park EJ, Kang EM (2005) Effect of shopping mall attributes and shopping values on online purchase intentions. Journal of the Korean Society of Clothing and Textiles 29(11): 1475-1484.

16. Kang JY, Johnson KK, Wu J (2014) Consumer style inventory and intent to social shop online for apparel using social networking sites. Journal of Fashion Marketing and Management, 18(3): 301-320.

17. Khan MA, Ali AJ (2012) Factors affecting customers' intention towards online shopping in Bangladesh. Indonesian Management \& Accounting Research 11(1): 21-36.

18. Preez RD, Visser EM, Zietsman L (2007) Profiling male apparel consumers: Lifestyle, shopping orientation, patronage behaviour and shopping mall behaviour. Management Dynamics 16(1): 2-19.

19. Rothschild ML (1984) Perspectives on involvement: current problems and future directions. Advances in Consumer Research 11: 216-217.

20. Wang CC, Yang HW (2008) Passion for online shopping: The Influence of personality and compulsive buying. Social Behavior and Personality 36(5): 693-705.

21. Lee SE, Littrell MA (2005) Global e-tailing: US consumers' intention to shop for cultural products on the internet. International Journal of Retailing and Distribution Management 33(2): 133-147.

22. Chen T (2008) Impulse purchase varied by products and marketing Journal of International Management Studies: 154-161.

23. Sia CL, Lim KH, Leung K, Lee MK, Huang WW, et al. (2009) Web Strategies to Promote Internet Shopping: Is Cultural-Customization Needed? MIS Quarterly 33(3): 491-512.

24. Cao Y, Gruca TS, Klemz BR (2003) Internet pricing, price satisfaction, and customer satisfaction. Int J Electronic Commerce 8(2): 31-50.

25. Belk RW (1988) Possessions and the extended self. J Consumer Research 15(2): 139-168

26. Passyn KA, Diriker M, Settle RB (2011) Images of online versus store shopping: have the attitudes of men and women, young and old really changed? Journal of Business \& Economics Research 9(1): 99-110.

27. Wen C, Prybutok VR, Xu C (2011) An integrated model for customer online repurchase intention. J Computer Information Systems 52(1): $14-23$

28. Liu C, Arnett KP (2000) Exploring the factors associated with web site success in the context of electronic commerce. Information \& Management 38(1): 23-33.

29. Jiang P, Rosenbloom B (2005) Customer intention to return online: price perception, attribute-level performance, and satisfaction unfolding over time. European Journal of Marketing, 39(1/2): 150-174.

30. Johnson C, Ein-Gar D (2008) Being hedonic and becoming prudent. Advances in Consumer Research, 35: 957-957.

31. (2016) Web-influenced retail sales in the United States from 2014 to 2020.

32. Vyncke P (2002) Lifestyle segmentation: From attitudes, interests and opinions, to values, aesthetic styles, life visions and media preferences. European J Communication 17(4): 445-463.

33. Hsu MH, Chuang LW, Hsu CS (2013) Understanding online shopping intention: the roles of four types of trust and their antecedents. Internet Research 24(3): 332-352.

34. Du Preez R, Visser E, Zietsman L (2007) Lifestyle, shopping orientation, patronage behavior and shopping mall behaviour- a study of South 
African male apparel consumers. European Advances in Consumer Behaviour 8: 279-280.

35. Rogers EM (1995) Diffusion of innovation. (4 $4^{\text {th }}$ edn), The Free Press, Newyork, USA.

36. Smith R, Deitz, G, Royne MB, Hansen JD, Grünhagen M, et al. (2013) Cross-cultural examination of online shopping behavior: A comparison of Norway, Germany, and the United States. Journal of Business Research 66(3): 328-335.

37. Blackwell RD, Miniard PW, Engel JF (2001) Consumer Behavior. $\left(9^{\text {th }}\right.$ edn), Harcourt College Publishers, USA, p.570.
38. Lima Filho DO, Alves CS, Quevedo-Silva F, Moreira LB, Garcez VR, et al. (2012) Profile of the electronic commerce consumer: A study with Brazilian university students. Journal of Internet Banking and Commerce 17(1): 1-17.

39. Breitenbach CS, Van Doren DC (1998) Value-added marketing in the digital domain: enhancing the utility of the Internet. J Consumer Marketing 15(6): 558-575.

40. Tsai YC, Yeh JC (2010) Perceived risk of information security and privacy in online shopping: A study of environmentally sustainable products African Journal of Business Management 4(18): 4057-4066. 